Dariusz Kasprzak ${ }^{1}$

Uniwersytet Papieski Jana Pawła II w Krakowie

\title{
Ojcostwo duchowe w myśli patrystycznej - zarys zagadnienia
}

We współczesnej teologii duchowości katolickiej kwestia tzw. kierownictwa duchowego jest poruszana w ramach praktycznej te ol og i i du chow ości, gdzie stanowi zagadnienie szczegółowe w dziale „dydaktyka życia duchowego"2. Jest ono definiowane jako „indywidualna pomoc duchowa udzielana człowiekowi w jego dążeniu do doskonałości. Dla dzisiejszej teologii duchowości podobne znaczenie mają terminy: ojcostwo duchowe, zakładające rodzenie, dawanie życia duchowego; towarzyszenie duchowe, akcentujące partnerstwo między kierownikiem, potrzebę zaangażowania i osobistej odpowiedzialności kierownika i osoby kierowanej; dialog duchowy, poradnictwo i pomoc duchowa"s.

1 Dariusz Kasprzak OFMCap, ur. 1966 w Krakowie, prof. nadzw. w Uniwersytecie Papieskim Jana Pawła II w Krakowie (od 2012), pracownik Katedry Patrologii UPJPII, dr hab. nauk teologicznych w zakresie patrologii (PAT, Kraków 2008), dr nauk patrystycznych (Augustinianum, Rzym 1999), autor trzech monografii i sześćdziesięciu artykułów naukowych z zakresu patrologii. Ostatnio wydał: Duszpasterze V wieku. Studium porównawcze myśli pasterskiej św. Piotra Chryzologa i Salwiana z Marsylii (wyd. Unum, Kraków 2008). Główne kierunki zainteresowań: Kościół patrystyczny, patrystyczna egzegeza i teologia biblijna, teologia patrystyczna, duchowość okresu patrystycznego. E-mail: kdario@poczta.onet.pl.

2 Por. Schemat wykładu duchowości, [w:] Leksykonduchowości katolickiej, red. M. Chmielewski, Kraków-Lublin 2002, s. 22-23.

3 J. Misiurek, Kierownictwo duchowe, [w:] Leksykon duchowości katolickiej, dz. cyt., s. 411. 
Czytając teksty patrystyczne poświęcone formacji monastycznej, można odnieść wrażenie, że dla okresu ojców Kościoła właściwszym terminem określającym duchową pomoc i formacyjne towarzyszenie jest „ojcost wo duchowe”. Dlatego stosując metodologię nauk patrystycznych, po ukazaniu kwestii wstępnych (§§1-2), w oparciu o kluczowe w tej kwestii opracowania Jeana Daniélou ${ }^{4}$, Józefa Naumowicza ${ }^{5}$ i Anselma Grüna ${ }^{6}$, chcę wskazać, dlaczego dla okresu patrystycznego powinno się używać terminu „ojcostwo duchowe” oraz jakie były jego podstawowe praktyki (§§ 3-4).

\section{Biblia specjalnie nie mówi o kierownictwie duchowym}

Paweł Apostoł mówił o „rozeznawaniu duchów”, które zaliczał do głównych charyzmatów. Jednak w Nowym Testamencie nie znajdziemy zbyt wielu przykładów praktycznego opisu takiego rozeznawania duchów. Skutecznej pomocy w życiu duchowym innych wierzących dokonywali w ST patriarchowie, sędziowie czy prorocy (por. $1 \mathrm{Krl}$ 21, 17-29; Tb 4, 18; Koh 4, 10; Syr 4, 22). W Nowym Testamencie duchowym formatorem swych uczniów jest przede wszystkim Jezus Chrystus, udzielający swym naśladowcom napomnień, rad i wskazówek (por. Mk 8, 32-33; J 3, 1-21; 4, 7-26; Dz 9, 10-11), ale także Paweł (por. Tt, 1-2 Tm, Flm; 1 Kor 4, 16; Ga 4,$19 ; 1$ Tes $2,11-13)^{7}$.

4 Por. J. Daniélou, Kierownictwo duchowe w dawnej tradycji Kościoła, „Życie Duchowe” (2006) nr 48, s. 31-41; J. Daniélou, Kierownictwo duchowe w tradycji starożytnej, [w:] Sztuka kierownictwa duchowego. Poradnik dla księży, red. J. Augustyn, J. Kołacz, Kraków 2007, s. 131-141.

5 Por. J. Naumowicz, Ideały i upadki ojca duchowego według Jana Kasjana, [w:] Sztuka kierownictwa duchowego..., dz. cyt., s. 153-161; J. Naumowicz, Kierownictwo duchowe w tradycji monastycznej, [w:] Sztuka kierownictwa duchowego..., dz. cyt., s. 143-151; J. Naumowicz, Matki pustyni, [w:] Duchowość kobiety, red. J. Augustyn, Kraków 2007, s. 53-65.

6 Por. A. Grün, Droga pustyni. Kierownictwo duchowe w apoftegmatach, przekł. P. Włodyga, Kraków 1996.

7 Por. R. Machnik, Z historii kierownictwa duchowego, [w:] Sztuka kierownictwa duchowego..., dz. cyt., Kraków 2007, s. 113-114. 


\section{Teologia chrześcijańska I-III wieku mówi głównie o relacji mistrz-uczeń}

Od II wieku w teologii chrześcijańskiej wskazywano na relację mistrzuczeń ( $\delta\llcorner\delta \alpha ́ \alpha \kappa \alpha \lambda o \varsigma-\mu \alpha \theta \eta \tau \eta ́ \varsigma)$. Dużo w tym względzie zaczerpnięto wtedy z greckiej tradycji filozoficznej, gdzie od tysiąca lat istniała już tradycja prowadzenia uczniów przez mistrza jakiejś szkoły ${ }^{8}$. Wzorami takich klasycznych mistrzów greckich pozostawali Sokrates i Platon, a w tradycji łacińskiej głównie mistrzowie stoiccy, jak Seneka czy Marek Aureliusz. Mistrz miał odznaczać się cnotami miłości, dyskrecji, cierpliwości, rozeznawaniem słowa, pobożnością, łagodnością, ale i surowością w karaniu. Mistrzowie rozbudzali w swych uczniach właściwą dla swej szkoły filozoficznej skalę wartości, podkreślali zainteresowanie skutkami pracy nad sobą, dawali odpowiedzi na życiowe pytania swych uczniów. W okresie I-III wieku można wręcz mówić o istnieniu pogańskiej duchowości, która głosiła, iż prawdziwa filozofia jest sztuką dobrego życia (ars bene vivendi), która winna prowadzić filozofa do szczególnej troski o samego siebie oraz budzić w nim poczucie transcendencji ${ }^{9}$.

W III wieku Orygenes, korzystający z dziedzictwa filozofii greckiej oraz przekazu biblijnego, mówiąc o ojcostwie duchowym, określał je

8 Por. A. Kazimierczak-Kucharska, Aspekty procesu dążenia do doskonałego życia w filozofii greckiej i w chrześcijaństwie pierwszych wieków, „Studia Theologica Varsaviensia” 47 (2009) nr 2, s. $183-200$.

9 Por. P. Hadot, Filozofia jako ćwiczenie duchowe, przekł. P. Domański, Warszawa 2003, s. 165-166, 309-310. Zdaniem Pierre'a Hadota wewnątrz kategorii "troski o siebie samego" daje się zauważyć w filozofii antycznej okresu imperialnego powstawanie pewnego uczucia religijnego, zostają też wymyślone właśnie przez filozofów imperialnych „ćwiczenia duchowe”, które dla miłośników mądrości tamtej epoki były czymś fundamentalnym. Wskazówki poszczególnych szkół bardziej niż przeciwstawiać się sobie - wręcz przeciwnie - integrują się i wyznaczają swego rodzaju itinerarium w kierunku pełnej realizacji siebie samego, który to kierunek wszystkie filozofie imperialne wyznaczają jako swoją ostateczną metę. Można zatem stwierdzić, że zasadnicze zadania ćwiczeń filozofii starożytnej to: nauczyć się czytać, nauczyć się żyć, nauczyć się dialogować, nauczyć się umierać. Rezultat owej nauki jest dla filozofa owocem podejmowanych ćwiczeń i ascezy. Zob. też: D. Karłowicz, Arcyparadoks śmierci. Męczeństwo jako kategoria filozoficzna - pytanie o dowodową wartość męczeństwa, Kraków 2000; D. Karłowicz, Sokrates i inni święci. O postawie starożytnych chrześcijan wobec rozumu i filozofii, Warszawa 2005, s. 97-99. 


\section{Dariusz Kasprzak}

przede wszystkim jako duchowe towarzyszenie typu: mistrz i uczeń $\left(\delta\left\llcorner\delta \alpha^{\prime} \sigma \kappa \alpha \lambda \circ \varsigma, \mu \alpha \theta \eta \tau \eta^{\prime} \varsigma\right)^{10}\right.$. W opinii Adeli Monaci Castagno dla Orygenesa nauczanie tego typu było charyzmatem otrzymanym od Boga, po długim przygotowaniu moralnym i intelektualnym, natomiast nie wynikało z nadania zewnętrznego czy z władzy święceń (por. Komentarz do Ewangelii Jana 32, 122, gdzie Orygenes umieszcza urząd nauczyciela na trzecim miejscu, zaraz po apostołach i prorokach; por. 1 Kor 12, 28). Model idealnego nauczyciela był związany z ideałem doskonałości, gdzie $\delta\left\llcorner\delta \alpha^{\prime} \sigma \kappa \alpha \lambda\right.$ os skoncentrowany na studium i medytacji Pisma był także tym, który jest w stanie racjonalnie przekazywać to, co sam otrzymał i zdobył, oraz potrafi dostosowywać swe nauczanie do jakości moralnej i intelektualnej swego ucznia. Orygenes wzory takiego biblijnego postępowania odnajdywał w przykładach Mojżesza, Pawła, a przede wszystkim Chrystusa (por. Homilie do księgi Liczb 27, 12; Homilie do Księgi Powtórzonego Prawa 6, 6; 16, 2). Orygenesowski $\delta\llcorner\delta \alpha ́ \sigma \kappa \alpha \lambda$ o miał też mocne konotacje prorockie, co wiązało się z przekonaniem samego Orygenesa, że Pismo Święte jest przekazem przede wszystkim duchowym. Dlatego jedynym sposobem, aby je pojąć, jest alegoryczna - duchowa interpretacja tekstu biblijnego (por. Komentarz do Ewangelii Mateusza 10, 14; Komentarz łaciński do Ewangelii Mateusza 17, 20). W rozeznawaniu kwestii teologicznych Orygenes uznawał tradycję kościelną, która przekazuje nauczanie Kościoła otrzymane od apostołów w porządku sukcesji (por. 0 zasadach, Wstęp 2-3). Dzieła Orygenesa dokumentują też praktykę stałej modlitwy, podejmowanej, aby wzbudzać Boże natchnienia w nauczycielu i uczniach ${ }^{11}$.

Nauka w szkole Orygenesa (w Aleksandrii, a potem w Cezarei Palestyńskiej) rozpoczynała się od propedeutyki życia moralnego, która zarówno wskazywała na różne doktryny dotyczące koncepcji prawdziwego dobra i prawdziwego zła, zachęcała uczniów do dyskusji, jak i wskazywała na przykłady konkretnego życia, stymulując tym samym do osiągania

10 Por. M. Rizzi, Il $\delta\llcorner\delta \alpha ́ \sigma \kappa \alpha \lambda o \varsigma$ nella tradizone alessandrina. Da Clemente all',Oratio panegyrica in Origenem", [w:] Magister. Aspetti culturali ed istituzionali, a cura di G. Firpo, G. Zecchini, Alessandria 1999, s. 177-199.

11 Por. A. Monaci Castagno, Maestro, [w:] Origene. Dizionario. La cultura, il pensierro, le opere, a cura di A. Monaci Castagno, Roma 2000, s. 247-253. 
cnót (por. Grzegorz Cudotwórca, Mowa pochwalna ku czci Orygenesa 118). Następnie miała miejsce lektura i komentowanie tekstów filozoficznych, z wyjątkiem tych pism, które negowały istnienie Boga i jego opatrzności, aby ustalić, na ile mogą być brane pod uwagę do bezpośredniego studiowania wiedzy o Bogu z Biblii. Wyjaśnianiu tajemnic ukrytych w Piśmie Świętym służyła ostatnia część nauczania. Uczeń, naśladując swego mistrza, a ten ostatni na sposób Sokratesa bada dogłębnie dusze swego ucznia, wzbudza w nim pytania, słucha odpowiedzi, poprzez dialog i konfrontację wydobywa z ucznia inteligencję i zdolność do badania ponad oczywistość i tezy ogólne (por. Grzegorz Cudotwórca, Mowa pochwalna ku czci Orygenesa, 97) ${ }^{12}$.

Kontynuatorem tego typu myślenia był Grzegorz z Nyssy. W opinii Jeana Daniélou w okresie patrystycznym najbardziej szczegółowy wykład na temat porad duchowych i towarzyszenia duchowego znajdujemy w ostatnim rozdziale traktatu Grzegorza z Nyssy 0 dziewictwie (napisany w $371 \mathrm{roku})^{13}$. Pomimo tytułu pismo to stanowi bardziej apel skierowany do wszystkich chrześcijan, wzywający do postępowania zgodnego z Ewangelią ${ }^{14}$. Jak zaznacza Jean Daniélou, w analizowanym traktacie przekaz Grzegorza z Nyssy brzmi:

być chrześcijaninem w pełnym znaczeniu tego słowa to dążyć do ciągłego rozwijania w sobie życia duchowego, otrzymanego na chrzcie. W takim rozumieniu granice między ideałem monastycznym a zwykłym życiem chrześcijańskim były o wiele mniej wyraziste niż miało to miało miejsce później. W takiej perspektywie pojawiła się konieczność powstania szkół duchowości, które uczyłyby praktycznej mądrości chrześcijańskiej. Toteż wokół mężów duchowych zaczęli gromadzić się uczniowie. Tak powstała grupa słuchaczy skupionych wokół św. Antoniego, taką też była mała grupa przyjaciół, między którymi przebywali św. Jan Chryzostom i Teodor z Mopsuestii, ćwiczący się w życiu ewangelicznym przy Diodorze z Tarsu ${ }^{15}$.

12 Por. J. W. Żelazny, Szkoła Orygenesa w Cezarei Palestyńskiej - instytucja czy środowisko?, „Analecta Cracoviensia” (2006) nr 38-39, s. 421-429.

13 Por. J. Daniélou, Kierownictwo duchowe w tradycji starożytnej, dz. cyt., s. 132.

14 Por. J. Gribomont, Les Règles Morales de saint Basile et le Nouveau Testament, „Studia Patrística" (1957) nr 2, s. 417.

15 J. Daniélou, Kierownictwo duchowe w tradycji starożytnej, dz. cyt., s. 132. 
W tak pojmowanym rozwoju duchowym istotna jest zatem dalej osoba dobrego „przewodnika i mistrza” 16 , który potrafi wtajemniczyć młodych uczniów w arkana życia duchowego i kierować nimi ${ }^{17}$, gdyż życie duchowe narażone jest na szereg przeciwności i złudzeń ${ }^{18}$, których można uniknąć dzięki radzie kogoś doświadczonego ${ }^{19}$. Jak zaznacza Jean Daniélou, mistrz duchowy, jak np. Bazyli Wielki, potrafił sprawdzić, czy uczeń powierza mu swe grzechy, myśli i poruszenia ${ }^{20}$. W tym celu mistrz duchowy powinien najpierw obserwować, a następnie rozeznawać. Nie wystarczy, żeby znał duszę, trzeba jeszcze, by miał doświadczenie i wiedzę o działaniu duchów ${ }^{21}$. Mistrz duchowy powinien wreszcie umieć przystosowywać swe rady do różnych poziomów życia duchowego swych uczniów. Pisze

16 Gregorius Nyssenus, De virginitate. Epistola exhortatoria ad frugi vitam 24, PG 46, kol. 409; tłum. pol.: Grzegorz z Nyssy, O dziewictwie: „Większość tych, którzy obierają życie dziewicze, to ludzie młodzi i niedoświadczeni. Dlatego powinni się przede wszystkim przyłożyć do szukania dobrego przewodnika (kathegemón) i mistrza (didaskalos) tej drogi, bojąc się, by z powodu swojej ignorancji nie zeszli z drogi prawej i nie weszli w ślepy zaułek błędów" (przekład w: J. Daniélou, B. Dyduła, Kierownictwo duchowe w tradycji starożytnej, dz. cyt., s. 133-134).

17 Grzegorz z Nyssy, O dziewictwie 24, PG 46, kol. 412; tłum. pol.: „Reguły szczegółowe dotyczą sposobu życia, jakie będzie prowadził ten, kto obrał tę formę doskonałości (philosophia), oraz określają to, czego winien przestrzegać, w jakich zajęciach się ćwiczyć, podają miarę ascezy (enkrateia), sposób zachowywania się i wszystko, co prowadzi do tego celu, jaki każdy winien dokładnie poznać. Wiele dokumentów pisanych poucza o tych sprawach, jednakże bardziej skuteczne niż pouczanie słowami jest wychowywanie czynami", przekład w: J. Daniélou, B. Dyduła, Kierownictwo duchowe w tradycji starożytnej, dz. cyt., s. 133.

18 Grzegorz z Nyssy, O dziewictwie 24, PG 46, kol. 414; tłum. pol.: „Niektórzy rzeczywiście mając najlepsze intencje w pragnieniu życia doskonałego, po wybraniu tego życia i po osiągnięciu pewnego stopnia doskonałości upadli nisko przez pychę, ulegając iluzji na skutek umysłowego zboczenia, które sprawiło, że za dobre uważali wszystko, co podsuwały im własne wyobrażenia", przekład w: J. Daniélou, B. Dyduła, Kierownictwo duchowe w tradycji starożytnej, dz.cyt., s. 134.

19 Grzegorz z Nyssy, O dziewictwie 24, PG 46, kol. 414; tłum. pol.: „Pomiędzy nimi są tacy, których mądrość (por. Prz 15, 19) nazywa leniwymi, którzy gorliwość w działaniu nakazanym przez Boga uważają za coś szkodliwego dla swojej duszy, lekceważą apostolskie przestrogi i nie jedząc własnego chleba w przyzwoity sposób, lecz otwierając usta na cudzy chleb, czynią z próżniactwa sposób na życie”, przekład w: J. Daniélou, B. Dyduła, Kierownictwo duchowe w tradycji starożytnej, dz. cyt., s. 134.

20 Por. Basilius Magnus, Regulae fusius tractatae 26: PG 31, kol. 985. 987; tłum. pol.: Bazyli Wielki, Reguły dłuższe 26, [w:] Bazyli Wielki, Pisma ascetyczne, t. 2, przekł. J. Naumowicz, Kraków $2011^{2}$, s. 140 (Źródła Monastyczne, 6).

${ }^{21}$ J. Daniélou, Kierownictwo duchowe w tradycji starożytnej, dz.cyt., s. 137. 
o tym Grzegorz z Nyssy, O celu życia i prawdziwej ascezie (traktat napisany w 392 roku $)^{22}$.

\section{Ojcowie pustyni i tradycja „ojcostwa duchowego"}

Na temat ojcostwa duchowego w chrześcijaństwie zaczyna się więcej mówić dopiero od IV wieku, kiedy tradycja ta ukonstytuowała się w obrębie monastycyzmu egipskiego. Ojcem duchownym stał się mnich, do którego przychodzili jako uczniowie i u którego formowali się kandydaci na przeszłych mnichów ${ }^{23}$.Józef Naumowicz, badając kwestię „ojcostwa duchowego" w pierwotnym monastycyzmie, doszedł do konkluzji, iż poprawniejszym terminem na określenie duchowego towarzyszenia i formacji duchowej, jaka odbywała się w ramach przyjaznej relacji i więzi monastycznego formatora z wychowankiem, jest termin „ojcostwo”24. Śledząc

22 Gregorius Nyssenus, De instituto christiano 62: PG 46, kol. 297. 299; tłum. pol.: Grzegorz z Nyssy, 0 celu życia i prawdziwej ascezie: „Ci, którzy stoją na czele tego duchowego chóru, winni zdawać sobie sprawę z ważności swoich starań, zważać na podstępy zła zagrażające wierze i walczyć stosownie do swej funkcji, tak by z tej racji nigdy nie unieść się pychą. Istnieje bowiem takie niebezpieczeństwo. Niektórzy sądzą, że mają władzę nad innymi, i prowadzą ich do życia niebiańskiego, a tymczasem niepostrzeżenie gubią siebie przez własną pychę. W sprawowaniu swej funkcji przełożeni winni czynić więcej wysiłków niż inni, czuć się bardziej pokorni niż ci, którymi zarządzają, własnym życiem dawać wzór służby, a w powierzonych im braciach widzieć depozyt Boga"; Gregorius Nyssenus, De instituto christiano 64: Dbajcie więc o nich - kontynuował Grzegorz - jak dobrzy wychowawcy o delikatne dzieci, powierzone im przez rodziców. Biorą oni pod uwagę charakter dzieci i stosują różne środki: raz karcą, innym razem napominają lub chwalą, itp. Nie kierują się względami czy niechęcią, ale czynią to, co jest stosowne w danej sytuacji i czego wymaga usposobienie dziecka. Tak, aby ono samo nauczyło się szlachetnie postępować w swym życiu", [w:] Grzegorz z Nyssy, O naśladowaniu Boga. Pisma ascetyczne, przekł. J. Naumowicz, Kraków 2001, s. 119 (Biblioteka Ojców Kościoła, 15); por. J. Daniélou, Kierownictwo duchowe w tradycji starożytnej, dz. cyt., s. 139-140.

${ }_{23}$ Por. J. Daniélou, Kierownictwo duchowe w dawnej tradycji Kościoła, dz. cyt., 31-41.

24 J. Naumowicz, Kierownictwo duchowe w tradycjimonastycznej, dz. cyt., s. 153-154: „ojcowie duchowi stanowili centralne postacie, bez których ojcostwo duchowe byłoby nie do pomyślenia. To dzięki nim u swego początku osiągnęło ono niebywały poziom i stało się wzorem dla późniejszych wieków. Pisma z tego okresu wskazują także, że określenie: „kierownictwo duchowe" może być niewystarczające. Abba nie oznaczał jedynie kierownika w sprawach duchowych. Relacja ucznia do starca była relacją ucznia do mistrza albo raczej syna 
rozważania Józefa Naumowicza, można w nich wyróżnić osiem zasadniczych przesłanek, przemawiających w monastycyzmie antycznym za „ojcostwem duchowym”, a nie za „kierownictwem duchowym”.

(1) wolny wybór poczatkujących ascetów, którzy wytrwale szukali mnicha doświadczonego w modlitwie, ascezie i walce duchowej, który mógłby stać się dla nich przewodnikiem duchowym; przy wybranym ojcu kandydaci na mnichów najczęściej pozostawali, obdarzali go zaufaniem i wiernością, przedstawiali mu swoje myśli i prosili o radę, by czynić postępy w życiu duchowym ${ }^{25}$;

(2) doświadczonego mnicha najczęściej nazywano đ̊ßßó (aram. ojciec,

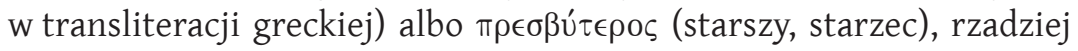
$\delta\left\llcorner\delta \alpha ́ \sigma \kappa \alpha \lambda o \varsigma\right.$ (nauczyciel, mistrz) ${ }^{26}$;

(3) w poradnictwie duchowym ojców pustyni poznanie intelektualne i element dydaktyczny schodziły na dalszy plan, wręcz znikały, natomiast priorytetem stawało się znalezienie drogi zbawienia. Ten typ praktyki duchowej odzwierciedlało często zadawane pytanie: „Ojcze, co mam czynić, aby się zbawić?” lub „Powiedz słowo dla mego zbawienia”27;

(4) odpowiedzi danego ojca były bardzo proste, serdeczne i ciepłe, nigdy nieformułowane jako teoretyczne i abstrakcyjne zasady, ale jako praktyczne, dobrane do potrzeb duchowych pytającego, drobne rady, które dany uczeń miał zawsze pamiętać, aby stały się one częścią jego życia wewnętrznego ${ }^{28}$;

(5) istotne było dzielenie życia z uczniami, przekazywanie osobistego doświadczenia życia chrześcijańskiego, modlitwy, ascezy, ciszy. Było to

do ojca. Ojciec duchowny dawał swemu uczniowi nie kodeks spisanych czy ustnych reguł ani zestaw technik medytacji, ale osobistą relację. Niekiedy mógł udzielać swym uczniom dokładnych wytycznych bądź ścisłych odpowiedzi. Ale zawsze były dawane w ramach osobistej relacji. Wiele rzeczy bowiem nie mogło być wyrażonych słowami poza bezpośrednim spotkaniem osobowym. Tak więc u Ojców pustyni nie najważniejsze było nauczanie, kierowanie czy też kształcenie, ale formacja duchowa w ramach osobowej relacji, to znaczy w ramach przyjaznej i osobowej więzi starca ze swymi uczniami. Dlatego w przypadku monastycyzmu wczesnochrześcijańskiego, który zrodził się na Wschodzie, a potem rozwinął się też na Zachodzie, bardziej słuszne jest mówić o «ojcostwie» niż o «kierownictwie duchowym»".

25 Por. J. Naumowicz, Kierownictwo duchowe w tradycji monastycznej, dz. cyt., s. 143-144.

26 Por. J. Naumowicz, Kierownictwo duchowe w tradycji monastycznej, dz. cyt., s. 144.

27 Por. J. Naumowicz, Kierownictwo duchowe w tradycji monastycznej, dz. cyt., s. 144-145.

28 Por. J. Naumowicz, Kierownictwo duchowe w tradycji monastycznej, dz. cyt., s. 145. 
możliwe ponieważ uczniowie mieszkali przy ojcu duchownym, lub w jego pobliżu, widzieli go, modlili się z nim, pracowali i jedli, mając w nim wzór czy to solidnie wykonywanej pracy, czy zażyłości życia z Bogiem w rozmaitych formach pobożności, jak ewangeliczna małość ${ }^{29}$ czy posłuszeństwo $^{30}$. Dlatego największe błędy ojców duchowych powstawały wtedy, gdy ktoś przekazywał nauki innym, a sam ich nie praktykował, lub jeśli komuś brakowało właściwego doświadczenia. Błędy ojca duchowego mogły wywołać u uczniów oziębłość lub rozpacz ${ }^{31}$;

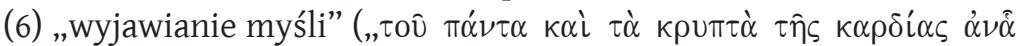

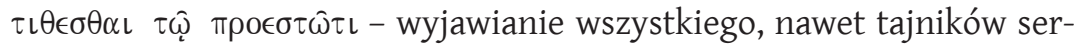
ca przełożonemu"32), czyli praktyka duchowa polegająca na wyjawianiu ojcu duchowemu przez ucznia wszystkich swych myśli, wewnętrznych poruszeń, odczuć i duchowych stanów. Praktyka ta miała na celu obiektywizację myśli i pragnień, dostrzeżenie rzeczywistych celów duchowych, zrozumienie nie zawsze uświadomionych motywacji i ukrytych niebezpieczeństw, a ostatecznie chodziło o poznanie przez ucznia samego siebie i swego wnętrza. Ojciec duchowy pomagał uczniowi rozeznać, czy jego myśli i pragnienia są dobre, czy złe, także te dotyczące przesadnej ascezy. Ojciec zatem wspólnie z uczniem rozeznawał, czy mnich nie kieruje się w swej pracy duchowej iluzjami ${ }^{33}$, czy ma właściwą motywację duchową, czy zachowuje właściwą miarę w swych duchowych i ascetycznych postanowieniach. Wyjawianie myśli ojcu duchowemu było warunkiem

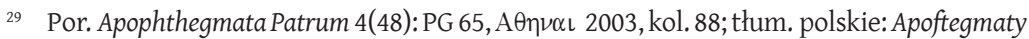
Ojców pustyni 42, t. 1: Gerontikon - Księga Starców, przekł. M. Borkowska, oprac. M. Starowieyski, Kraków 1994, s. 136 (Źródła Monastyczne, 4).

30 Por. Apoftegmaty Ojców pustyni 526-527, t. 2: Kolekcja systematyczna, przekł. M. Kozera, oprac. M. Starowieyski, J. Pollok, Kraków 1995, s. 242-243 (Źródła Monastyczne, 9); por. J. Naumowicz, Kierownictwo duchowe w tradycji monastycznej, dz. cyt., s. 145-146.

31 Por. J. Naumowicz, Ideały i upadki ojca duchowego według Jana Kasjana, dz. cyt., s. $157-158$.

32 Basilius Magnus, Regulae fusius tractatae 26: PG 31, kol. 985. 987; tłum. pol.: Bazyli Wielki, Reguły dłuższe 26 [w:] Bazyli Wielki, Pisma ascetyczne, t. 2, przekł. J. Naumowicz, Kraków 2011², s. 140 (Źródła Monastyczne, 6); por. Apoftegmaty Ojców pustyni (t. 1) 38: „[Abba Antoni] Powiedział także: «Jeśli to możliwe, mnich powinien wyjawić starcom nawet, ile kroków robi albo ile kropel pije u siebie w celi: żeby sprawdzić, czy może i w tym nie błądzi»", PG 65, kol. 88, s. 134.

33 Por. Apoftegmaty Ojców pustyni 37, PG 65, kol. 88; s. 134. 
postępu duchowego, natomiast zatajanie myśli i poleganie na własnym osądzie uznawano za niebezpieczeństwo duchowe prowadzące do pychy duchowej. Udzielanie porad podczas wyjawiania myśli nie było pierwotnie związane z posługą prezbitera - spowiednika, choć z czasem - w późniejszych wiekach - obie role mogły się łączyć. Tytuł „ojca” czy „starca” był związany właśnie z tą funkcją rozeznania duchowego, a przyznawano go jedynie tym mnichom, którzy byli doświadczeni w ascezie, odznaczali się charyzmatem udzielania słowa drugiemu, darem wyciszenia. Ojcowie duchowi byli świadomi tego, że w pełnym znaczeniu tego słowa prawdziwym ojcem duchowym dla chrześcijan jest jedynie osoba Ducha Świętego, dlatego starali się w swej posłudze jedynie towarzyszyć uczniom w ich drodze do Boga, a nie być nieomylnymi sędziami życia drugiego wierzącego ${ }^{34}$.

Technicznym terminem, którym od IV wieku zaczęto określać władzę

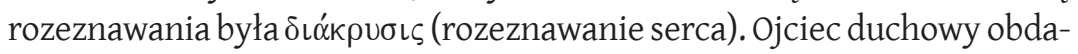
rzony darem rozeznawania serc, który łączył się ze zdolnością k $\alpha \rho \delta i ́ o \gamma \nu \hat{\omega}$

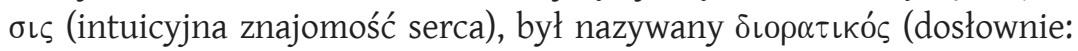
„ten, kto potrafi przejrzeć na wskroś”) ${ }^{35}$. Miał doprowadzić ucznia do stanu $\alpha \pi \alpha \dot{\theta} \epsilon \iota \alpha$, przez który Ewagriusz Pontyjski (por. Centuria VI, 52) rozumie „zdrowie duszy”, czyli wolność od wszelkich namiętności ${ }^{36}$. Ten stan jest zaś niezbędny do wprowadzenia ucznia w kontemplację Boga Trójjedynego, co zdaniem Ewagriusza stanowi ostateczny cel ojcostwa duchowego;

(7) nauczanie i przekaz ojca duchownego cechowały się łagodnością, życzliwością, serdecznością i łaskawością. Postawa łagodności (

34 Por. J. Naumowicz, Kierownictwo duchowe w tradycji monastycznej, dz. cyt., s. 147-150. Jak zaznacza J. Naumowicz, Kierownictwo duchowe w tradycji monastycznej, dz. cyt., s. 152-153, tradycja wyjawiania myśli przed doświadczonym duchowo chrześcijaninem stała się normą także w późniejszej tradycji monastycznej, jak choćby w cenobityzmie bazyliańskim (por. Bazyli, Reguły dłuższe 26), w monastycyzmie bizantyjskim (wybór tzw. pnuematikos czyli doświadczonego nauczyciela, kapłana bądź mnicha) czy tradycja starców w monastycyzmie rosyjskim XIX wieku.

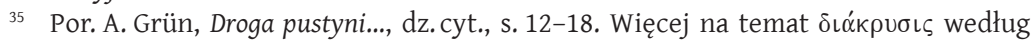
ojców pustyni zob.: J. T. Lienhard, On “Discernment of Spirits” in the early Church, „Theological Studies” 41 (1980), nr 3, s. 505-529; A. D. Rich, Discernment in the Desert Fathers: diákrisis in the life and thought of early Egyptian monasticism, Milton Keynes 2007.

36 Solidne studium o rozumieniu $\pi \dot{\alpha} \theta$ o $\varsigma$ i $\alpha \dot{\alpha} \alpha \dot{\theta} \epsilon\llcorner\alpha$ w apoftegmatach ojców pustyni napisał w j. polskim M. Kozera, Ideały Ojców pustyni. Pathos i apatheia, Lublin 2000. 
wobec ucznia prowadziła bowiem do Boga i miała otwierać na Jego miłość. Stąd zalecenia np. Ewagriusza z Pontu do ojców duchowych, aby nie denerwowali się na swych uczniów, gdy ci nie czynią postępów w życiu duchowym, ale byli jak lekarze: życzliwie i wytrwale kierowali opornych ku dobru. Istotna w postawie łagodności ojca duchowego wobec ucznia była także postawa współczucia, które u człowieka roztropnego wywołuje nie mniejszą skruchę niż groźba (por. Ewagriusz z Pontu, 0 mistrzach i uczniach 14). Bez życzliwości i dobroci przenikanie tajników ludzkiego serca byłoby niszczące. Ojcowie pustyni byli bowiem przekonani, że głosząc i mówiąc w imieniu Boga, sami winni okazywać dobroć i życzliwość, bo to uwiarygadniało taką naukę̧;

(8) ojciec duchowy modlił się stale za swych uczniów, czując się odpowiedzialny za ich postęp duchowy i zbawienie, przyjmował na siebie ich trudy i słabości, cierpiał z nimi i za nich (por. Barsanufiusz Gazy, List 35; 235) ${ }^{38}$.

\section{Praktyka - sztuka duchowego ojcostwa według ojców pustyni}

Opierając się na badaniach Anselma Grüna poświęconych doświadczeniom duchowego ojcostwa we wczesnym monastycyzmie chrześcijańskim, pragnę teraz zarysować sposoby takiego duchowego towarzyszenia, uprawianego przez ojców pustyni. Grün zarysowuje konkretny schemat takich działań duchowych, stosowanych przez pierwszych mnichów: konkretna rada, pocieszać i zachęcać, modlitwa błagalna i solidarność, odpowiedź udzielana przez symboliczne działanie, nie pozbawiać decyzji, odmowa udzielenia rady, troskliwie doprowadzać do prawdy, Diakrisis - czyli dar rozeznawania, dopuszczać uczucia i potrzeby, odpowiedź przez koan, kierownictwo drogą okrężną, duchowe prowadzenie przez kobiety. Jego zdaniem apoftegmaty nigdzie nie opisują kierownictwa ciągłego, ale tylko notują pojedyncze odpowiedzi udzielane pytającym w konkretnych sytuacjach. Mimo to pozwalają odkryć pewne pod-

37 Por. J. Naumowicz, Kierownictwo duchowe w tradycji monastycznej, dz. cyt., s. 150.

38 Por. J. Naumowicz, Kierownictwo duchowe w tradycji monastycznej, dz.cyt., s. 151; por. A. Grün, Droga pustyni..., dz. cyt., s. 24-25. 


\section{Dariusz Kasprzak}

stawowe rysy. Wyraźnie widać, że ojcowie nigdy nie trzymali się jakichś wyuczonych metod, ale na pytania braci odpowiadali, czerpiąc z własnego wewnętrznego doświadczenia. Nie studiowali metod, ale poznawali siebie w długich duchowych zmaganiach i poznawali Boże tajemnice $\mathrm{w}$ radykalnym poszukiwaniu Boga ${ }^{39}$.

(1.) Konkretna $\mathrm{rada}^{40}$. Wiele apoftegmatów stanowi odpowiedź na konkretne pytania typu: „Co mam czynić?”, „Ojcze, powiedz słowo!”. Odpowiedzi są przeróżne, w zależności od duchowego stanu pytającego („milcz i nie mierz samego siebie” ${ }^{11}$ czy „nie ufaj własnej sprawiedliwości, nie troszcz się o to, co minęło, a powściągnij swój język i brzuch" ${ }^{42}$ ). Ojcowie pustyni wyraźnie dostrzegali, czego pytający potrzebuje, by dojść do prawdy, spotkać Boga i powierzyć Mu siebie. W odpowiedzi chodziło o jedno ćwiczenie, dwa lub trzy aspekty życia, na które mnich powinien szczególnie uważać ${ }^{43}$. Doradzane przez ojców ćwiczenie uruchamia proces duchowego wzrostu i umożliwia nieustanne życie w Bożej obecności. Jeżeli mnich nieustannie pracuje nad jednym punktem (np. nad milczeniem czy wyrozumiałością wobec innych), postąpi na swej drodze, dojdzie do ludzkiej dojrzałości, do spotkania z Bogiem, w końcu do oświecenia. Decyduje wykonanie polecenia ojca. Ważnym tematem w ojcostwie duchowym były konkretne działanie mnicha, porządek dnia, sposób modlitwy, metoda medytacji.

(2.) Pocieszać i zachę caćc ${ }^{44}$. Bardzo ważną zasadą ojca duchowego było nie sądzić, nie zasmucać, ale pocieszać i podnosić na duchu. Ojciec duchowy był wręcz opisywany jako duchowy pocieszyciel braci ${ }^{45}$. W żadnym razie nie mógł sprawić, aby pytający odchodził zasmucony, bo to nie była dla niego żadna pomoc. Ojciec duchowy winien zdać się na pojętność ucznia i nie wymagać zbyt wiele ${ }^{46}$. Dar rozeznania wyma-

39 Por. A. Grün, Droga pustyni..., dz. cyt., s. 29-110.

40 Por. A. Grün, Droga pustyni..., dz. cyt., s. 29-37.

41 Apoftegmaty Ojców pustyni 165, PG 56, kol. 141; s. 186.

42 Apoftegmaty Ojców pustyni 6, PG 56, kol. 77, s. 126.

43 Apoftegmaty Ojców pustyni 385: „w każdej sprawie stawiaj sobie to pytanie: «Kimże ja jestem?» i nie sądź nikogo", PG 56, kol. 223; s. 276.

44 Por. A. Grün, Droga pustyni..., dz. cyt., s. 37-46.

45 Por. Apoftegmaty Ojców pustyni 597, PG 56, kol. 328; s. 374.

46 Por. Apoftegmaty Ojców pustyni 596, PG 56, kol. 328; s. 374. 
gał, aby wczuwał się i rozumiał ucznia, aby brał pod uwagę jego skłonności i predyspozycje, historię jego życia, jego rany i doradzał mu to, co w jego sytuacji może prowadzić wzwyż ${ }^{47}$. Ojcowie na przeróżne sposoby próbowali pokrzepiać mnichów, którzy byli przygnębieni i zrezygnowani. Celem pocieszenia ucznia często starzec sobie przypisywał błąd, z powodu którego inny się skarżył ${ }^{48}$.

(3.) Modlitwa błagalna i solidarnośćc ${ }^{49}$. Ojciec duchowy nie tylko udzielał rady, ale też modlił się za poszukujących i znał ich bolączki. Także po swej śmierci ojciec modlił się za ucznia przebywającego jeszcze na ziemi. W modlitwie solidaryzował się z nim. Wiedział, że jedynie Bóg potrafi przemienić cierpienie człowieka. Modlitwa ojca nie zastępowała jednak walki, jaką podejmował uczeń. Dzięki modlitwie duchowy ojciec stawał się bardziej otwarty na stan proszącego. W modlitwie ojciec duchowy wyrażał miłość względem brata poszukującego rady i przedstawiał Bogu swoją niemoc, wiedząc że uzdrowić i przemienić potrafi tylko Bóg ${ }^{50}$.

(4.) Odpowiedź udzielana przez symboliczne działa ni $\mathrm{e}^{51}$. Często ojcowie wskazywali na właściwą drogę nie przez słowa, ale przez symboliczne działanie ${ }^{52}$. Kiedy np. mnisi osądzali brata, który popełnił grzech, abba Mojżesz wziął dziurawy worek, napełnił go piaskiem i niósł na plecach. Kiedy spotkali go mnisi i pytali co ma znaczyć jego zachowanie, ten im odpowiedział: „Moje grzechy sypią mi się za plecami, a ja ich nie widzę, a przychodzę dzisiaj sądzić cudze winy. Kiedy to usłyszeli, nic już nie powiedzieli tamtemu bratu, ale mu przebaczyli" ${ }^{33}$.

(5.) Nie pozbawiać decyzji $i^{54}$. Ojcowie wzbraniali się przed pozbawianiem proszącego o radę możności decydowania. Często swymi radami naprowadzali go na doświadczenie, które pomagały mu znaleźć rozwią-

\footnotetext{
Por. Apoftegmaty Ojców pustyni 387, PG 56, kol. 229; s. 277.

Por. Apoftegmaty Ojców pustyni 636, PG 56, kol. 336. 337; s. 382.

Por. A. Grün, Droga pustyni..., dz.cyt., s. 47-50.

Por. Apoftegmaty Ojców pustyni 16, PG 56, kol. 80; s. 128.

Por. A. Grün, Droga pustyni..., dz. cyt. s. 50-52.

Por. Apoftegmaty Ojców pustyni 20, PG 56, kol. 81; s. 129.

Apoftegmaty Ojców pustyni 496, PG 56, kol. 281, 284; s. 329.

Por. A. Grün, Droga pustyni..., dz. cyt., s. 53-56.
} 
zanie. Ojcowie duchowi nie chcieli podejmować decyzji za ucznia; każdy miał decydować sam o sobie. Byli natomiast pomocą innym w odkrywaniu sensu ich myśli i pomocą w podejmowaniu decyzji, podając na przykład kryteria poprawnej decyzji ${ }^{55}$.

(6.) Odmowa udzielenia rady ${ }^{56}$. Czasami ojcowie nie udzielali żadnej odpowiedzi każąc mówić swemu milczeniu ${ }^{57}$. Milczenie nakłaniało poszukujących rady do przejścia z poziomu teoretycznego na poziom doświadczenia ${ }^{58}$. Jeżeli ojciec długo nie odpowiadał poszukującemu rady, osłabiał w pytającym pewność siebie i mobilizował go do stawiania pytań samemu sobie. Milczenie czyniło pytającego bardziej otwartym na odpowiedź. Mnisi odmawiali rady zawsze wtedy, gdy dostrzegali, że pytającemu nie zależy na jej wypełnieniu, ale jedynie pragnie się chwalić słowem znanego ojca ${ }^{59}$.

(7.) Troskliwie doprowadzać do prawdy ${ }^{60}$. Było metodą rozmowy bez jakichkolwiek wskazówek, która nie daje drugiemu żadnej odpowiedzi na pytanie, ale przez rozmowę stopniowo prowadzi go ku samodzielnemu odkryciu tego, co dla niego dobre. W apoftegmatach ojców spotykamy tę metodę, w której ojciec nie odpowiadał uczniowi, ale najpierw pozwalał mu z całkowitym spokojem wyjaśnić, co on sam o nich myśli, stawiając przy tym pytania. W końcu udawało mu się tak naświetlić te praktyki, że uczniowie stawali w obliczu ich wątpliwej wartości. Same słowa nie zawsze pokazują, czy jakaś duchowość jest autentyczna, czy nie. Reakcje, zwłaszcza silne emocje, jak gniew lub zdenerwowanie, wskazują, że motywacja nie współbrzmi z życiem duchowym, że chodzi o jakieś własne interesy, a nie o poszukiwanie Boga ${ }^{61}$.

(8.) Diakrisis, czyli dar rozeznawania ${ }^{62}$. Dar rozeznawania był podstawową umiejętnością każdego ojca duchowego ${ }^{63}$. Mający go szyb-

55 Por. Apoftegmaty Ojców pustyni 391, PG 56, kol. 229, 232; s. 278.

56 Por. A. Grün, Droga pustyni..., dz.cyt., s. 56-59.

57 Por. Apoftegmaty Ojców pustyni 305, PG 56, kol. 197; s. 245.

58 Por. Apoftegmaty Ojców pustyni 582, PG 56, kol. 321, 324;, s. 369-370.

59 Por. Apoftegmaty Ojców pustyni 763, PG 56, 368, 369; s. 412.

60 Por. A. Grün, Droga pustyni..., dz.cyt., s. 60-65.

${ }_{61}$ Por. Apoftegmaty Ojców pustyni 446, PG 56, kol. 303-304.

62 Por. A. Grün, Droga pustyni..., dz.cyt., s. 65-67.

63 Por. Apoftegmaty Ojców pustyni 626, PG 56, kol. 333; s. 380. 
ciej dochodził w rozmowie do punktu, o który rzeczywiście chodzi. Miał wyczucie tego, co jest wskazane dla pytającego ${ }^{64}$.

(9.) Dopuszczać uczucia i potrzeby ${ }^{65}$. Ojcowie pustyni uczyli swych uczniów dopuszczać do głosu swe potrzeby i odczucia, by rzeczywiście mogły zostać przemienione. Wiedzieli oni, że w namiętnościach drzemią pozytywne siły, a tylko to, co zostało zauważone, może zostać zmienione. Jeżeli przez ascezę pokonałbym pożądania od razu, być może byłoby to często również zahamowaniem. Przemiana była przebiciem się przez schematy, role i maski, nie tłumiła ich, lecz sięgała do fundamentu pożądań i namiętności. Zrozumienie, że przez odreagowanie zarówno pozytywnych, jak i negatywnych uczuć można doznać ulgi, dokonywało się w sposób uporządkowany przez konkretne zadania, które zadawał uczniom ojciec duchowy. To przeobrażało uczucia ucznia tak, że na koniec otwierał się na Boga, który wyzwala człowieka ze wszelkich zależności ${ }^{66}$.

(10.) O d p owiedź przez „koan"67. Niekiedy ojcowie pustyni odpowiadali na pytania przez słowo, które - na pierwszy rzut oka niezrozumiałe - zmuszało jednak do przekroczenia poziomu rozumu i odkrycia rzeczywistości religijnej, która ostatecznie może zostać wyrażona jedynie w słowach niezrozumiałych.W tej odpowiedzi ojciec wahał się przed udzieleniem pytającemu gotowej recepty. Często pytający oczekiwał odpowiedzi, której mógłby się trzymać. Ale w ten sposób nie postąpiłby sam w swym myśleniu, ale zrzuciłby odpowiedzialność na ojca duchowego. Dlatego ojcowie duchowi dawali pytającemu słowo, które nie rozwiązywało problemu, lecz zmuszało pytającego do dalszych poszuki-

\footnotetext{
64 Por. Apoftegmaty Ojców pustyni 386, PG 56, kol. 228, 229; s. 276-277.

65 Por. A. Grün, Droga pustyni..., dz. cyt., s. 67-73.

66 Por. Apoftegmaty Ojców pustyni 476, PG 56, kol. 272; s. 319; Apoftegmaty Ojców pustyni 572, PG 56, kol. 313. 316; s. 361-362.

${ }^{67}$ Por. A. Grün, Droga pustyni..., dz. cyt., s. 73-75. Ten sposób odpowiedzi A. Grün przyrównuje do praktyki koan jaka występuje w medytacji zen, gdzie jest zadaniem, którego rozwiązanie drogą logicznego myślenia nie jest możliwe, zagadką nierozwiązywalną, ponieważ zawierającą sprzeczność. Ojcowie Pustyni odpowiadali na pytania uczniów często tak, jak mistrzowie zen.
} 
wań, aż wyjaśni się zagadka ich życia i zrozumieją, kim jest Bóg i czego od nich wymaga ${ }^{68}$.

(11.) Kie rownictwo drogą o krężnąa ${ }^{69}$. Drogi mnichów nie zawsze były proste i zmierzające jedynie do celu, wielu mnichów było wcześniej złoczyńcami. Ojcowie pustyni nie wpadali w panikę, kiedy przychodził do nich mnich, który wpadł w grzechy. Ufali w to, że Bóg nawet poprzez grzechy potrafi przyprowadzić człowieka do siebie i że nie o własnych siłach, ale tylko dzięki łasce Bożej i Bożemu miłosierdziu pytający może wytrwać. Stawał się dobrym mnichem nie przez pouczenie, ale przez doświadczenie ${ }^{70}$.

(12.) Duchowe prowadzenie przez kobiety ${ }^{71}$. Kierownictwo duchowe u ojców pustyni nie było sprawą wyłącznie mężczyzn, ale też i kobiet, choć w pierwotnym anachoretyzmie jego przedstawicielki były nieliczne. Grün wyróżnił kilka aspektów typowych dla kobiecego towarzyszenia duchowego: właściwe kobietom porównania i obrazy (np. porównywanie cnoty stałości do troskliwego zachowania ptasiej mamy); kwestię, że przez umiar potrafimy odróżnić Bożą ascezę od szatańskiej ${ }^{72}$; macierzyńską troskę o wszystko, czego potrzebuje człowiek; wyrozumiałość dla wieku, słabości i choroby; pojmowanie celu ascezy nie w dyscyplinie czy rezygnacji, lecz w łagodności ${ }^{73}$.

$$
* * *
$$

68 Por. Apoftegmaty Ojców pustyni 714: „Powiedział także: «Za pierwszym razem uciekaj, za drugim uciekaj, za trzecim stań się mieczem»”, PG 56, kol. 357; s. 398; por. też Apoftegmaty Ojców pustyni 776, PG 56, kol. 372. 373; s. 415-416.

${ }_{69}$ Por. A. Grün, Droga pustyni..., dz. cyt., 75-77.

70 Por. Apoftegmaty Ojców pustyni 789, PG 56, kol. 380; s. 422-423.

71 Por. A. Grün, Droga pustyni..., dz. cyt., s. 77-81.

72 Por. Apoftegmaty Ojców pustyni 906, PG 56, kol. 425; s. 469.

73 Por. Apoftegmaty Ojców pustyni 902, PG 56, kol. 425; s. 468. Z tłumaczeń apoftegmatów matek pustyni zobacz: L. Swan, Zapomniane matki pustyni, Pisma, życie i historia, przekł. P. Kaźmierczak, Kraków 2005; Meterikon. Mądrość Matek Pustyni, red. M. Bagin, A. A. Thiermeyer, przekł. B. Widła, Warszawa 2010. Ważnymi studiami poświęconymi duchowości matek pustyni są w j. polskim: B. Ward, Nierządnice pustyni. Pokuta we wczesnych źródłach monastycznych, przekł. P. Długosz, Poznań 2005; J. Naumowicz, Matkipustyni..., dz. cyt., s. 53-65; T. Paszkowska, Kobiece rozeznawanie - wybrane przypadki, http://www.kurs-biblijny.pl/wp-content/uploads/2014/05/ 7-Kobiece-rozeznawanie---wybrane-przypadki.pdf(19.01.2015), por. szczególnie § 4. Rozeznawanie kobiece na pustyni w starożytności, s. 7-15. 
W swoich rozważaniach Jean Daniélou i Anselm Grün stosują termin „kierownictwo duchowe” jako termin techniczny, który prawdopodobnie zwyczajowo rozciągają na praktykę ojcostwa duchowego w starożytności chrześcijańskiej. Natomiast Józef Naumowicz tytułuje co prawda swe opracowania jako studia poświęcone „kierownictwu duchowemu”, ale preferuje określenie „ojcostwo”. Zdaniem Naumowicza termin „ojcostwo duchowe” jest poprawniejszy dla okresu patrystycznego, gdyż wynika merytorycznie z tekstów ojców pustyni i jest w nich poświadczony jako nazwa przez odniesienie się do „ojca” duchowego (abba).

W Piśmie Świętym nie znajdujemy praktycznego opisu prowadzenia duchowego, a pierwsze trzy wieki chrześcijaństwa bardziej wskazują na relację duchową typu mistrz-uczeń. Ojcostwo duchowe rodziło się wśród anachoretów i cenobitów egipskich z wolnego wyboru ojca i danego ucznia, poświadczają je stosowane terminy (ojciec, ojciec duchowy, starzec; rzadziej nauczyciel, mistrz). Ojcostwo duchowe praktykowane przez ojców pustyni było spersonalizowanym duchowym ćwiczeniem polegającym na znalezieniu drogi zbawienia. Istotne dla ojcostwa duchowego praktykowanego przez ojców pustyni było osobiste przeżycie duchowe, którym ojcowie dzielili się ze swymi uczniami, a nie rada i przekaz wiedzy teologiczno-duchowej. Ojcostwo duchowe było także wspólnotą życia ojca i uczniów. Opierało się na relacji serdeczności, dzieleniu życia chrześcijańskiego, przekazywaniu osobistego doświadczenia, praktyce wyjawiania myśli i rozeznawania duchowego. Ojca duchowego cechowała postawa łagodności i życzliwości oraz stałej modlitwy za swych uczniów, ich duchowy postęp i ostateczne zbawienie.

Rady ojców nie stanowiły zatem terapii psychologicznej, nie były też autorytarne i moralistyczno-nakazowe, jak w przypadku późniejszego historycznie kierownictwa duchowego. W ojcostwie duchowym istniała relacja ojciec-uczeń, rada była poparta wspólnotą życia monastycznego i praktyczną modlitwą ojca za uczniów. Ojcostwo duchowe nie było więc duchowym doradztwem czy nakazowym poradnictwem. Celem ojcostwa duchowego było dojście do dojrzałości chrześcijańskiej, przejawiającej się w duchu rozeznania siebie, kontemplacji, wewnętrznego 
spokoju i apathei. Natomiast w kierownictwie duchowym, skoncentrowanym od XVI wieku na pouczeniach moralno-duchowych, celem było doprowadzenie kierowanego do umiejętności rozeznawania duchowego oraz do większego posłuszeństwa, większej dyspozycyjności i większego podporządkowania się Bogu i przełożonym. 


\section{Summary}

\section{Ojcostwo duchowe w myśli patrystycznej - zarys zagadnienia}

W Biblii oraz w pierwotnej tradycji chrześcijańskiej (I-III wiek) nie spotykamy opisów praktycznego prowadzenia duchowego. Jako ćwiczenie duchowe ojcostwo duchowe powstało dopiero w IV wieku wśród mnichów egipskich. Celem podstawowym tej praktyki było znalezienie sposobu na własne zbawienie, zaś celami doraźnymi były: dojście do dojrzałości chrześcijańskiej, przejawiającej się w duchu rozeznania siebie, osiągnięcie kontemplacji, wewnętrznego spokoju i apathei. Wiodącym wątkiem formacyjnym $\mathrm{w}$ ojcostwie duchowym $\mathrm{u}$ omawianych mnichów było dzielenie się osobistymi przeżyciami duchowymi, szczególnie istotna była zaś praktyka wyjawiania swych myśli.

Słowa klucze: ojcostwo duchowe, ojciec duchowy, starzec, patrologia, ojcowie pustyni

\section{Spiritual Paternity in Patristic Literature - an Outline}

The practical description of spiritual leaderships is not mandated as an institution in Sacred Scripture. The Christianity of the first three centuries presents us rather the spiritual relationship between the master and his disciple. Spiritual paternity as a spiritual discipline started in the $4^{\text {th }}$ century within the Egyptian coenobitic communities and anchorites. It resulted in new terms such as: father - Abba, spiritual father, teacher, senior, spiritual master. The spiritual paternity of the Desert Fathers was a personalized spiritual exercise, which was to seek the way of salvation. The ultimate goal was to reach spiritual maturity, which manifested itself in the soul's recognition, contemplation, inner peace and apatheia. The Father of the Desert used to share their own spiritual experiences with their disciples rather than to give them advice or hints or intellectual lessons. The relationship of spiritual paternity was built on the pattern: father and disciple. Every advice was supported by the prayer for the spiritual children and the example of the monastic life. The spiritual paternity relayed on cordial relations, sharing prayer and community life, the practice of self-revelation and soul recognition and the transitions their own personal experiences. The spiritual father was gentle, friendly and prayerful. Such a practice of spiritual fraternity was neither the archaic form of psychological therapy nor the spiritual direction. Spiritual father begetted his sons to God. His aim was to help his spiritual children in their own spiritual development in order to attain the ultimate salvation.

Keywords: Spiritual paternity, spiritual father, patrology, Desert Fathers 


\section{Bibliografia}

Apophtegmata Patrum, Migne, PG 65, kol. 71-440, tłum. pol.: Apoftegmaty Ojców pustyni (por. Apophtegmata Patrum - editio F. Nau; Les Apophtegmes des Pères, vol. 1-3).

Basilius Magnus, Regulae fusius tractatae: PG 31, 889-1305; tłum. pol.: Bazyli Wielki, Reguły dłuższe 26, [w:] Bazyli Wielki, Pisma ascetyczne, t. 2, przekł. J. Naumowicz, Kraków $2011^{2}$ (Źródła Monastyczne, 6).

Apophtegmata Patrum - editio F. Nau, ,Revue de l'Orient Chrétien” 10 (1905), s. 387417; „Revue de l'Orient Chrétien” 12 (1907), s. 48-69, s. 171-181, s. 393-404; „Revue de l'Orient Chrétien” 13 (1908), s. 47-57, s. 266-283; „Revue de l'Orient Chrétien” 14 (1909), s. 357-379; „Revue de l'Orient Chrétien” 17 (1912), s. 204-211, s. 294-301; „Revue de l'Orient Chrétien” 18 (1913), s. 137-146; przekład francuski całego zbioru: L. Regnault, Les sentences des Pères du Désert, nouveau recueil, Solesmes 1970, s. 13-162; tłum. pol.: Apoftegmaty Ojców pustyni, t. 4: Zbiór anonimowy wydany przez François Nau, przekł. M. Borkowska, E. Dąbrowska, M. Pawlik, oprac. S. Hiżycki, Kraków 2013 (Źródła Monastyczne, 64).

Daniélou J., Kierownictwo duchowe w dawnej tradycji Kościoła, „Życie Duchowe” (2006) nr 48, s. 31-41.

Daniélou J., Kierownictwo duchowe w tradycji starożytnej, [w:] Sztuka kierownictwa duchowego. Poradnik dla księży, red. J. Augustyn, J. Kołacz, Kraków 2007, s. 131-141.

Gregorius Nyssenus, De instituto christiano:PG 46, kol. 287-306; tłum. pol.: Grzegorz z Nyssy, 0 celu życia i prawdziwej ascezie, [w:] Grzegorz z Nyssy, O naśladowaniu Boga. Pisma ascetyczne, Kraków 2001, s. 99-137 (Biblioteka Ojców Kościoła, 15).

Gregorius Nyssenus, De virginitate. Epistola exhortatoria ad frugi vitam 24, PG 46, kol. 409-416; tłum. pol.: Grzegorz z Nyssy, Traktat o dziewictwie, przekł. fragmentów 24 rozdz.: J. Daniélou, tłum. B. Dyduła, Kierownictwo duchowe w tradycji starożytnej [w:] Sztuka kierownictwa duchowego. Poradnik dla księży, red. J. Augustyn, J. Kołacz, Kraków 2007, s. 131-141.

Gregorius Thaumaturgos, In Origenem oratio panegyrica: PG 10, kol. 1051-1104; tłum. pol.: Grzegorz Cudotwórca, Mowa pochwalna na cześć Orygenesa, przekł. S. Kalinkowski, Kraków 1998 (Źródła Myśli Teologicznej, 11).

Gribomont J., Les Règles Morales de saint Basile et le Nouveau Testament, „Studia Patrística" (1957) nr 2, s. 416-426.

Grün A., Droga pustyni. Kierownictwo duchowe w apoftegmatach, przekł. P. Włodyga, Kraków 1996.

Hadot P., Filozofia jako ćwiczenie duchowe, przekł. P. Domański, Warszawa 2003.

Karłowicz D., Arcyparadoks śmierci. Męczeństwo jako kategoria filozoficzna - pytanie o dowodowa wartość męczeństwa, Kraków 2000.

Karłowicz D., Sokrates i inni święci. O postawie starożytnych chrześcijan wobec rozumu i filozofii, Warszawa 2005. 
Kazimierczak-Kucharska A., Aspekty procesu dażenia do doskonałego życia w filozofii greckiej i w chrześcijaństwie pierwszych wieków, „Studia Theologica Varsaviensia” 47 (2009) nr 2, s. 183-200.

Kozera M., Ideały Ojców pustyni. Pathos i apatheia, Lublin 2000.

Les Apophtegmes des Pères, vol.1. Collection systématique. Chapitres 1-9, SCh 387, red. J. C. Guy, Paris 1997; tłum. pol.: t. 1: Gerontikon-Księga Starców, przekł. M. Borkowska, oprac. M. Starowieyski, Kraków 1994 (Źródła Monastyczne, 4).

Les Apophtegmes des Pères, vol. 2. Collection systématique. Chapitres 10-16, SCh 474, red. J. C. Guy, Paris 2003; tłum. pol.: Kolekcjasystematyczna, przekł. M. Kozera, oprac. M. Starowieyski, J. Pollok, Kraków 1995 (Źródła Monastyczne, 9).

Les Apophtegmes des Pères, vol. 3, Collection systématique. Chapitres 17-21, SCh 498, red. J. C. Guy, Paris 2005; tłum. pol.:Zbiory etiopskie (wybór). Mniejsze zbiory greckie. Zbiory łacińskie. Opowiadania dla duszy pożyteczne: Pawła z Monemwazji,Jana Moschosa (wybór), przekł. S. Kur, M. Rymuza, M. Starowieyski, oprac. M. Starowieyski, R. Zarzeczny, Kraków 2011 (Źródła Monastyczne, 56).

Lienhard J. T., On „Discernment of Spirits” in the Early Church, „Theological Studies” 41 (1980) nr 3, s. 505-529.

Machnik R., Z historii kierownictwa duchowego, [w:] Sztuka kierownictwa duchowego. Poradnik dla księży, red. J. Augustyn, J. Kołacz, Kraków 2007, s. 113-127.

Meterikon. Mądrość Matek Pustyni, red. M. Bagin, A.A. Thiermeyer, przekł. B. Widła, Warszawa 2010.

Misiurek J., Kierownictwo duchowe, [w:] Leksykon duchowości katolickiej, red. M. Chmielewski, Kraków-Lublin 2002, s. 411-415.

Monaci Castagno A., Maestro, [w:] Origene. Dizionario. La cultura, il pensierro, le opere, a cura di A. Monaci Castagno, Roma 2000, s. 247-253.

NaumowiczJ., Ideałyi upadki ojca duchowego według Jana Kasjana, [w:] Sztuka kierownictwa duchowego. Poradnik dla księży, red. J. Augustyn, J. Kołacz, Kraków 2007, s. 153-161.

Naumowicz J., Kierownictwo duchowe w tradycji monastycznej, [w:] Sztuka kierownictwa duchowego. Poradnik dla księży, red. J. Augustyn, J. Kołacz, Kraków 2007, s. 143-151.

Naumowicz J., Matki pustyni, [w:] red. J. Augustyn, Duchowość kobiety, Kraków 2007, s. 53-65.

Paszkowska T., Kobiece rozeznawanie - wybrane przypadki, http://www.kurs-biblijny. pl/wp-content/uploads/2014/05/7-Kobiece-rozeznawanie---wybrane-przypadki. pdf (19.01.2015).

Rich A. D., Discernment in the Desert Fathers: diákrisis in the life and thought of early Egyptian monasticism, Milton Keynes 2007.

Rizzi M., Il $\delta\llcorner\delta \alpha ́ \sigma \kappa \alpha \lambda o \varsigma$ nella tradizone alessandrina. Da Clemente all',,Oratio panegyrica in Origenem", [w:] Magister. Aspetti culturali ed istituzionali, a cura di G. Firpo, G. Zecchin, Alessandria 1999, s. 177-199.

Schemat wykładu duchowości, [w:] Leksykon duchowości katolickiej, red. M. Chmielewski, Kraków-Lublin 2002, s. 20-24.

Swan L., Zapomniane matki pustyni, Pisma, życie i historia, przekł. P. Kaźmierczak, Kraków 2005. 
Ward B., Nierządnice pustyni. Pokuta we wczesnych źródłach monastycznych, przekł. P. Długosz, Poznań 2005.

Żelazny J. W., Szkoła Orygenesa w Cezarei Palestyńskiej - instytucja czy środowisko?, „Analecta Cracoviensia” (2006) 38-39, s. 421-429. 